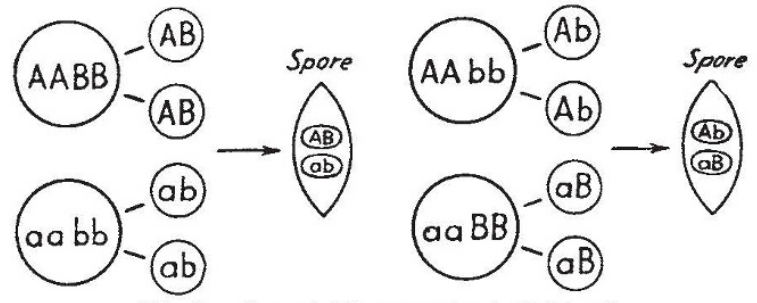

Fig. 1. $A a$ and $B b$ segregate at division $\mathrm{r}$.
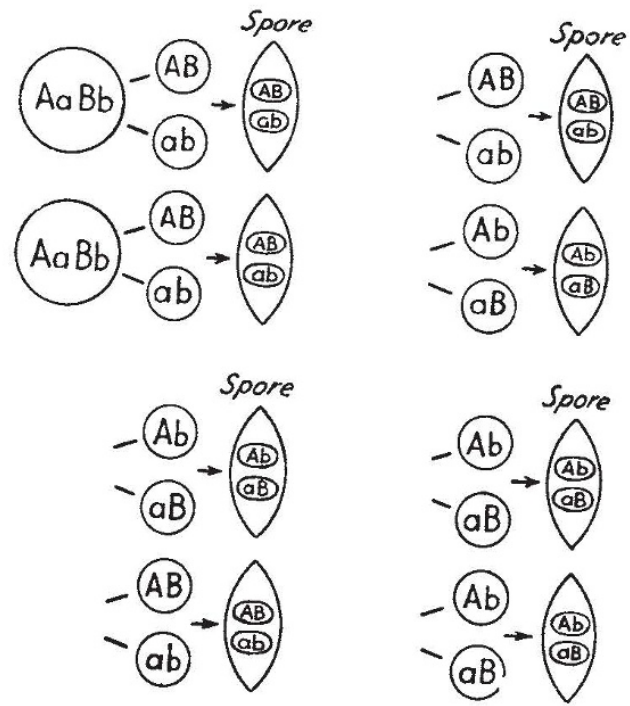

Fig. 2. $A a$ and $B b$ segregate at division II.I

only two $7 d$ ascospores being found out of very many examined. The nuclear components of the 4 ascospores of 45 asci, 360 in all, were determined by obtaining somatic segregates of the ascospore cultures. Twenty-five asci contained spores of the $A d, a D$ type and twenty contained the $A D$, ad type. No ascus contained more than one type of spore. This indicates that the $A a$ and $D d$ factors usually segregate independently of each other at the flrst division. The $V v$ factors behave differently. Dodge et al. list 78 asci in which segregation of this factor does not occur and 39 asci in which $v v$ and $V D$ ascospores are found. This indicates that the $V v$ factors frequently some distance from the centromere.

Suppression of segregation, like that shown by the $D d$ factors, is expected to occur whenever the recombinations of factors of the $A a$ type are restricted to the products of one meiotic division.

Department of Cryptogamic Botany,

E. R. SANSOME.

University of Manchester.

Jan. 31.

'Dodge, B. O., Schmitt, B. Mary, and Appel, Anita, Proc. Amer. Phil. Soc., 89, 4, 575 (1945).

\section{Genetics of Woodlice}

I HAVE previously recorded in Nature ${ }^{1}$ the results of a series of experiments I have made during the past two and a half years with two varieties of Armadillidium vulgare (Latr.), namely, Howard's type $D$ and rufobrunneus Cllge.

In my last experiment I took one of the females of the brood of 52 females of rufobrunneus and crossed it with its male parent (type $D$ ), and as a result $I$ obtained a brood of 37 , all referable to the var. rufobrunneus. The brood consisted of 22 females and 15 males. There was no trace of the type $D$. Thus the var. rufobrunneus reproduced itself in both sexes.

I next took one of the males of this brood of rufobrunneus and paired it with two females of the same variety kindly sent to me by Dr. Hamilton E. Quick from Langland Bay, Swansea, Glam. As a result, I outained two broods: one consisting of 37 females and 13 males, and the other of 43 females and 17 males, all referable to the var. rufobrunneus. The preponderance of females is noticeable. It is thus evident that the variety has again reproduced itself in both sexes and has eliminated the $D$-type strain entirely.

I have since tried to cross members of these two broods in order to ascertain if they would breed true, or if the Howard Type $D$ orde appear again, but so far I have not met with any success.

The Hollies, 141 Fulford Road, WAITRR E. COLLINGE.

$$
\text { York. }
$$

${ }^{1}$ Nature, 154, 797 (1944); 155, 670 (1945).
New Records of Eucrangonyx gracilis S. I. Smith and Gammarus tigrinus Sexton

DURING a survey of the River Avon from Rugby to Stratford-onAvon and of its tributary the River Sowe, new records of the amphipods Eucrangonyx gracilis and Gammarus tigrinus were made. The survey, Which took place in August 1944, was made on behalf of the Water Pollution Research Laboratory of the Department of Scientific and Industrial Research, and the results are published by permission of the Department. General faunistic collections were made at stations several miles apart on the Avon, from Bretford Bridge to Stratford, and on the Sowe from Foleshill to its confluence with the Avon. Amphipods were absent from the Sowe except at Sowe Bridge, where a flourishing population of Gammarus tigrinus was present. In the very small tributary, the Smite, which joins the Sowe at this point, two $G$. pulex only were taken.

On the Avon, eight of the seventeen stations visited had no amphipods, probably because of an unsuitable substratum. At the other stations amphipods were nowhere abundant, and Bretford was the only station with a fair number present. These were mainly Gammarus pulex, but four $G$. tigrinus were also taken. In the thirteen miles from Stare Bridge to Barford Bridge collections at ten stations yielded only twenty-one amphipods; these were Gammarus pulex and Eicrangony gracilis in approximately equal numbers. Eucrangonyx was also present at Alveston Ferry and Tiddington, a few miles above Stratford.

According to Crawford ${ }^{1}$, Eucrangonyx gracilis is a recent importation from North Amerfca. In a private communication, Mr. G. M Spooner infor it in 1938 is publishing some notes on the species, having taken it in 1938 in well-separated localities in the Midlands. These included the River Avon at Tewkesbury, the Stratford-on-Avon (anal and Eariswood Reservoir in Warwickshire. It has been recorded by Rei

from Middlesex and is probably widely distributed in the Midlands.

Gammarus tigrinus was described by Sexton ${ }^{3}$ from specimens taken in the Droitwich district. Mr. G. M. Spooner (unpublished) has seen stricted to the Severn-Avon watershed; the present records fit that distribution.

In view of the suggestion in Sexton's paper that $G$. tigrinus was In view of the suggestion in Sexton's paper that $G$. tigrinus was
inhabiting waters of peculiar composition, a request was made to the Water Pollution Research Laboratory, which has supplied the following analyses.

TABLE 1. COMPOSITION IN MILII-EQUIVALENTS PER LITRE OF SAMPLIES OF WATER COLLECTED ON SEPTEMBER 8, 1945, FROM RIVER AVON, NEAR COVENTRY. ANALYSES BY WATER POLLUTYON RESEARCH

\begin{tabular}{|c|c|c|c|c|c|}
\hline $\begin{array}{l}\text { Sampling } \\
\text { point }\end{array}$ & $\begin{array}{c}\text { Bretford } \\
\text { Bridge }\end{array}$ & $\begin{array}{c}\text { Stare } \\
\text { Bridge }\end{array}$ & $\begin{array}{l}\text { Blackdown } \\
\text { Mill }\end{array}$ & $\begin{array}{c}\text { Sowe } \\
\text { Bridge }\end{array}$ & $\begin{array}{l}\text { The } \\
\text { Smite }\end{array}$ \\
\hline $\begin{array}{l}\text { Constituents: } \\
\mathrm{Na}+\text { (calc.) } \\
\mathrm{Ca}++ \\
\mathrm{Mg}+ \\
\text { Total cations } \\
\mathrm{Cl}^{\prime} \\
\mathrm{SO}_{4}{ }^{\prime \prime} \\
\mathrm{HCO}_{3}{ }^{\prime \prime} \\
\mathrm{CO}_{3}{ }^{\prime \prime} \\
\text { Total anions }\end{array}$ & $\begin{array}{r}3 \cdot 60 \\
6 \cdot 80 \\
3 \cdot 10 \\
13 \cdot 50 \\
2 \cdot 33 \\
6 \cdot 07 \\
4 \cdot 10 \\
\text { nil } \\
13 \cdot 50\end{array}$ & $\begin{array}{r}5 \cdot 57 \\
6 \cdot 10 \\
2 \cdot 70 \\
14 \cdot 37 \\
5 \cdot 43 \\
5 \cdot 04 \\
3 \cdot 90 \\
\text { nil } \\
14 \cdot 37\end{array}$ & $\begin{array}{r}7 \cdot 68 \\
5 \cdot 45 \\
2 \cdot 20 \\
15 \cdot 33 \\
5 \cdot 85 \\
5 \cdot 38 \\
4 \cdot 10 \\
\text { nil } \\
15 \cdot 33\end{array}$ & $\begin{array}{r}26 \cdot 06 \\
8 \cdot 15 \\
4 \cdot 30 \\
38 \cdot 51 \\
28 \cdot 71 \\
4 \cdot 60 \\
5 \cdot 20 \\
\text { nil } \\
38 \cdot 51\end{array}$ & $\begin{array}{c}0 \cdot 52 \\
5 \cdot 95 \\
2 \cdot 20 \\
8 \cdot 67 \\
1.01 \\
2 \cdot 06 \\
5 \cdot 60 \\
\text { nil } \\
8 \cdot 67\end{array}$ \\
\hline$p \mathrm{H}$ value at & $7 \cdot 5$ & $7 \cdot 3$ & $7 \cdot 3$ & $7 \cdot 6$ & $7 \cdot 8$ \\
\hline $\begin{array}{l}\text { Total solids at } \\
180^{\circ} \mathrm{C} \text {. } \\
\text { (gm./l.) }\end{array}$ & 0.857 & $1 \cdot 040$ & $1 \cdot 051$ & $2 \cdot 259$ & 0.497 \\
\hline
\end{tabular}

There is evidence of high sodium chloride content at Sowe Bridge as, for example, in Wyken Slough (cooper, in Sexton ${ }^{8}$ ), but the presence of $G$. tigrinus at Bretford Bridge indicates that this high content is not always necessary.

$$
\begin{gathered}
\text { Department of 7oology, } \\
\text { The University, }
\end{gathered}
$$

Nature, 139, 327 (1937)

${ }^{2}$ Synopses of Brit. Fauna No. 3. Gammaridæ (Linn. Soc Lond., 1944). 3. Mar. Biol. Assoc., 23, 543 (1939).

\section{Substances Related to Vitamin A}

THE successful and indeed most notable synthesis of "vitamin A acid', that is, the $C_{30}$ acid corresponding to the $\mathrm{C}_{20}$ alcohol, was described recently by . F. Arens and D. A. van Dorp ${ }^{2}$. The publication of certain results which we have obtained while working on similar ines appears to be desirable.

We have been interested for some time in the application of Reformatsky reactions employing $\omega$-bromo-ethylenic esters in syntheses in the vitamin A series. In our hands the condensation of methyl $\omega$-bromocrotonate with $\beta$-ionone (regenerated from the semicarbazone) yielded an ester mixture, which, on hydrolysis, gave the crystalline $\mathrm{C}_{17}$-acid (I) in 15 per cent overall yield from $\beta$-ionone, as a yellow crystalline solid, m.p. $160^{\circ}$ uncorrected. (We presume that the m.p. (115.5-157.5 $5^{\circ}$ corrected) quoted by the Dutch authors is a misprint.) Our light-absorption data (max. $3250 \mathrm{~A}$., $\log s=4 \cdot 51$ ) are in agreement with those quoted by the Dutch authors, and in 